\title{
Transfer of Rhizobium loti, Rhizobium huakuii, Rhizobium ciceri, Rhizobium mediterraneum, and Rhizobium tianshanense to Mesorhizobium gen. nov.
}

\author{
B. D. W. JARVIS, ${ }^{1 *}$ P. VAN BERKUM ${ }^{2}$ W. X. CHEN,${ }^{3}$ S. M. NOUR,${ }^{4}$ \\ M. P. FERNANDEZ, ${ }^{4}$ J. C. CLEYET-MAREL, ${ }^{5}$ AND M. GILLIS ${ }^{6}$ \\ Department of Microbiology and Genetics, Massey University, Palmerston North, New Zealand ${ }^{1}$; BARC-West, \\ Agricultural Research Service, U.S. Department of Agriculture, Beltsville, Maryland 20705'2 Department of \\ Microbiology, College of Biology, Beijing Agricultural University, Beijing, People's Republic of China ${ }^{3}$; \\ Centre National de la Recherche Scientifique, UMR 5557, Université Lyon 1, 69622 Villeurbanne \\ Cedex, ${ }^{4}$ and Institut National de la Recherche Agronomique, Laboratoire de la Recherche \\ sur les Symbiotes des Racines, 34060 Montpellier, ${ }^{5}$ France; and Laboratorium \\ voor Microbiologie, Universitiet Gent, B-9000 Ghent, Belgium ${ }^{6}$
}

\begin{abstract}
Reasons are advanced for removal of Rhizobium ciceri, Rhizobium huakuii, Rhizobium loti, Rhizobium mediterraneum, and Rhizobium tianshanense from the genus Rhizobium and for establishment of Mesorhizobium gen. nov. for these species. A description of the genus Mesorhizobium and amended descriptions of Mesorhizobium ciceri, Mesorhizobium huakuii, Mesorhizobium loti, Mesorhizobium mediterraneum, and Mezorhizobium tianshanense are provided.
\end{abstract}

In a review of root nodule symbioses by Vincent (22), the fast-growing rhizobia associated with Lotus comiculatus and Lupinus densiflorus were recognized as a separate group which merited a specific designation, and the name Rhizobium loti was tentatively proposed for it. Approval for the designation of $R$. loti as a new species was also voiced at a roundtable discussion on Rhizobium taxonomy associated with the 4th International Congress on Nitrogen Fixation at Canberra, Australia, in 1980. The subsequent publication of the new species in 1982 (9) enabled it to be included in a revised taxonomy of the Rhizobiaceae presented by Jordan in Bergey's Manual of Systematic Bacteriology (12).

At that time $R$. lot $i$ was distinguished from other fast-growing rhizobia on the basis of flagellation (1), esterase patterns (14), response to isoflavonoids $(18)$, plant nodulation $(11,12)$, internal antigens (23), electrophoresis of soluble cellular proteins $(19,20)$, and DNA relatedness $(4,8)$. More recently, cellular fatty acid analysis was used to reveal differences, useful for identification purposes, between strains of $R$. loti and strains of the genus Agrobacterium and other Rhizobium or Sinorhizobium species (10). All of these methods differentiate species but give little indication of the relationships between species and genera.

An early indication of the relationship among $R$. loti, other Rhizobium species, and Sinorhizobium and Agrobacterium species was obtained by studying the intergeneric similarities of rRNA cistrons (7). The results of this analysis indicated that Rhizobium leguminosarum, Rhizobium galegae, Sinorhizobium meliloti, Sinorhizobium fredii, Agrobacterium tumefaciens (biovar 1), and Agrobacterium rhizogenes (biovar 2) were all more closely related to one another than they were to $R$. loti. Subsequent analyses of $16 \mathrm{~S}$ rRNA gene sequences of species in these genera have confirmed, refined, and extended this observation $(21,24,25)$; the levels of $16 \mathrm{~S}$ ribosomal DNA sequence similarity between $R$. loti and other Rhizobium and

\footnotetext{
* Corresponding author. Mailing address: Rivendell, 143 Old West Road, RD4, Palmerston North, New Zealand. Fax: 6463573089. E-mail: jarvis@manawatu.gen.nz.
}

Agrobacterium species are around $93.5 \%$. Consequently, there has been considerable support for the establishment of a separate genus for $R$. loti and related root nodule bacteria $(5,13$, 27).

The original description of $R$. loti (9) clearly indicated that fast-growing Lotus rhizobia formed part of an extensive plant cross-inoculation group involving plant species in the genera Lupinus, Ornithopus, Lotus, Anthyllis, Caragena, Astragalus, Ononis, Genista, and Mimosa. Jarvis et al. also indicated that the fast-growing Lotus rhizobia were related to rhizobia obtained from several plant species in these genera and also to rhizobia obtained from Cicer arietinum and Leucaena leucocephala. This finding was based on the work of Crow et al. (4), who found a group of rhizobia, identified as "group 4," which exhibited relatively high mean levels of DNA relatedness (50 to $51 \%$ ) with two fast-growing Lotus rhizobia used as reference strains but little relatedness (levels of DNA relatedness, 7 to $10 \%$ ) with reference strains derived from clover, bean, lucerne, or crown vetch (Coronilla varia). The group was genetically diverse since the levels of DNA relatedness between individual strains and the reference strains ranged from 36 to $88 \%$. These values suggested that group 4 probably included other species in addition to $R$. loti.

Since that time several other species of bacteria related to $R$. loti have been described. These species include Rhizobium huakuii from Astragalus sinicus (3), Rhizobium ciceri from Cicer arietinum (chickpea) (17), Rhizobium mediterraneum from chickpea (16), and Rhizobium tianshanense from an arid saline environment in northern People's Republic of China (2). In addition, De Lajudie et al. (5) identified "cluster U" as a group of strains from Acacia sp., Brazilian legumes, and Lotus sp. which is related to $R$. loti but exhibits considerable genetic heterogeneity. At least three new species can be recognized within cluster $U$. At present, these species and related strains can be said to constitute the " $R$. loti group."

The use of the genus Rhizobium for all of the fast-growing rhizobia, including $R$. leguminosarum, Rhizobium etli, Rhizobium tropici types A and B, Rhizobium meliloti, Rhizobium fredii, $R$. galegae, and the $R$. loti group defined above, has resulted in the formation of a polyphyletic genus which ob- 
TABLE 1. Some characteristics of Mesorhizobium species $^{a}$

\begin{tabular}{|c|c|c|c|c|c|}
\hline Characteristic & M. ciceri & M. huakuii & M. loti & M. mediterraneum & M. tianshanense \\
\hline \multicolumn{6}{|l|}{ Morphological characteristics } \\
\hline Flagellation & & $\begin{array}{l}\text { One polar or subpolar } \\
\text { flagellum }\end{array}$ & $\begin{array}{l}\text { One polar or subpolar } \\
\text { flagellum }\end{array}$ & & Peritrichous flagella \\
\hline Cell shape & Rods & Rods & Rods & Rods & Rods \\
\hline \multicolumn{6}{|l|}{ Colony characteristics } \\
\hline Opacity & Opaque & Semitranslucent & Opaque & Opaque & Opaque \\
\hline Diam $(\mathrm{mm})$ & $2-4$ & $2-4$ & $>1$ & 2 & $1-2$ \\
\hline Incubation time at $28^{\circ} \mathrm{C}$ (days) & $3-5$ & $5-6$ & 7 & $4-5$ & $5-7$ \\
\hline Color & Colorless & Colorless & Colorless & Colorless & Creamy \\
\hline \multicolumn{6}{|l|}{ Cultural characteristics } \\
\hline Maximum temp $\left({ }^{\circ} \mathrm{C}\right)$ & 40 & $37-39$ & $<39-40$ & 40 & $\mathrm{ND}^{b}$ \\
\hline $\begin{array}{l}\text { Maximum } \mathrm{NaCl} \text { concn for growth } \\
(\%, \mathrm{wt} / \mathrm{vol})\end{array}$ & 2.0 & ND & $<2.0$ & 2.0 & 1.0 \\
\hline $\mathrm{pH}$ range for growth & $5.0-10.0$ & $5.0-9.5$ & $4.0,<10.0$ & $>5.0,<10.0$ & ND \\
\hline $\mathrm{G}+\mathrm{C}$ content $(\mathrm{mol} \%)$ & $63-64$ & $59-64$ & $59-64$ & $63-64$ & $59-63$ \\
\hline \multicolumn{6}{|l|}{ Substrates used as sole carbon sources } \\
\hline D- and L-Arabinose & $t^{c}$ & + & + & + & $\mathrm{d}$ \\
\hline D-Fructose & + & + & + & + & $\mathrm{d}$ \\
\hline D- and L-Fucose & + & - & + & + & + \\
\hline Fumarate & + & + & + & + & - \\
\hline Inositol & + & - & + & + & - \\
\hline D- and L-Malate & + & + & + & + & - \\
\hline Maltose & + & + & + & + & $\mathrm{d}$ \\
\hline D-Raffinose & - & + & $\mathrm{d}$ & - & d \\
\hline Sucrose & + & + & + & + & d \\
\hline
\end{tabular}

${ }^{a}$ For the most part, the table includes only characteristics for which data are available for all five species. The only exception is flagellation; flagellation data are available for only three species. All species are gram-negative, non-spore-forming, rod-shaped bacteria which form circular, convex colonies on solid media under aerobic conditions and utilize D-glucose and rhamnose as sole carbon sources.

${ }^{b} \mathrm{ND}$, not determined.

${ }^{c}+$, used by all strains; d, used by some strains; -, not used by any strain.

scures the phenetic and phylogenetic differences among these species. The recent transfer of two species, $R$. meliloti and $R$. fredii, to the new genus Sinorhizobium (5) and the creation of two new species, Sinorhizobium saheli and Sinorhizobium teranga, have contributed to the resolution of this problem, but the remaining Rhizobium species still constitute a polyphyletic group. Further subdivision of the genus Rhizobium was recommended at a roundtable discussion on Rhizobium taxonomy associated with the 10th International Congress on Nitrogen Fixation at St. Petersburg, Russia, in 1995 (13), and a proposal was presented at the 15th North American Conference on Symbiotic Nitrogen Fixation (26). Participants at both of these meetings recognized that, based on $16 \mathrm{~S}$ rRNA sequence data, the species included in the $R$. loti group are monophyletic but are less closely related to other Rhizobium species ( $R$. leguminosarum, $R$. tropici types $\mathrm{A}$ and $\mathrm{B}$, and $R$. galegae) than are species already classified in related genera, such as the genera Sinorhizobium and Agrobacterium. The $R$. loti group is also phenetically and phylogenetically distinct from the other genera of nitrogen-fixing plant symbionts, the genera Azorhizobium and Bradyrhizobium. The purpose of this paper is to present the view that the species in the $R$. loti group should be reclassified in a new genus, the genus Mesorhizobium $(5,13$, 27).

The name Mesorhizobium is thought to have been originally proposed by W. X. Chen and coworkers. It was used by Peter Young at the International Symposium on Diversity and Taxonomy of Rhizobia at Wuhan, People's Republic of China, in 1994 for a phylogenetic group corresponding to the $R$. loti group defined above. Subsequently, Chen et al. (2) used the term "meso-growing rhizobia" when they described a new species, $R$. tianshanense, that is closely related to $R$. loti and $R$. huakuii. Thus, the name Mesorhizobium has been used to de- note both phylogenetic position and growth rate. The former meaning was emphasized at the workshop on Rhizobium taxonomy associated with the 10th International Congress on Nitrogen Fixation in St. Petersburg, Russia, (13), where it was used to indicate the intermediate position of the $R$. loti group between the Agrobacterium-Rhizobium-Sinorhizobium complex and the genera Azorhizobium and Bradyrhizobium in the alpha subdivision of the Proteobacteria. The meaning referring to the growth rate was emphasized by Young (26) at the 15th North American Conference on Symbiotic Nitrogen Fixation.

Characteristics of Mesorhizobium species described by Chen et al. (2, 3), De Lajudie et al. (5), Jarvis et al. (9), and Nour et al. $(16,17)$ are shown in Table 1 . For the most part Table 1 shows only characteristics available for all five species considered. An exception was made for flagellation data, which were available for only three species, because of the differences among Mesorhizobium huakuii, Mesorhizobium loti, and Mesorhizobium tianshanense. Additional information is available in the references mentioned above. Data for $R$. loti recorded by Nour et al. (16) and De Lajudie et al. (5) are included under this species. However, it should be recognized that the additional data are data only for the type strain (16) or the type strain and one other strain (5).

De Lajudie et al. (5) described a group of strains designated cluster $\mathrm{U}$, but since different phenotypic and genotypic groups were found among these bacteria, we concluded that although cluster U strains belong in the new genus Mesorhizobium, further study will be required before species can be described.

An examination of the comparative data available for the putative Mesorhizobium species revealed that $R$. ciceri, $R$. huakuii, $R$. loti, and $R$. mediterraneum have been compared previously by a number of different methods, including numerical taxonomy of phenotypic characteristics $(3,15,16)$, multilocus 
enzyme electrophoresis $(16,17)$, fatty acid analysis (10), restriction fragment length polymorphism of amplified $16 \mathrm{~S}$ rRNA sequences, including intergenic spacer sequences (16, 17), DNA-DNA hybridization $(3,16,17)$, and 16 S rRNA gene sequencing $(3,16,17)$. These techniques combined to give a good indication of the relationships among these four species. However, the relationship between these species and $R$. tianshanense is less clear. Previously published data for $R$. tianshanense include numerical taxonomy, DNA-DNA hybridization, and partial 16S rRNA gene sequence data (2). DNADNA hybridization data indicate that $R$. huakuii CCBAU $2609^{\mathrm{T}}$ and $R$. loti ATCC $33669^{\mathrm{T}}$ exhibit 32 and 64 or 34 and $40 \%$ DNA relatedness respectively, with two strains of $R$. tianshanense. A partial 16S rRNA gene sequence of $R$. tianshanense $\mathrm{A}-1 \mathrm{BS}^{\mathrm{T}}$ was identical to that of $R$. ciceri. Subsequent work (23a) revealed that the complete $16 \mathrm{~S}$ rRNA gene sequences of $R$. tianshanense A-1BS ${ }^{\mathrm{T}}$ and $R$, huakuii CCBAU $2609^{\mathrm{T}}$ differ by $2.1 \%$, while the sequences of $R$. ciceri and $R$. mediterraneum both differ from the $R$. tianshanense sequence by $3.6 \%$. However, a complete $16 \mathrm{~S}$ rRNA gene sequence for A-1BS ${ }^{\mathrm{T}}$ obtained by one of us (21b) revealed a closer relationship among $R$. tianshanense, $R$. ciceri, $R$. hukauii, and $R$. mediterraneum. We concluded that $R$. tianshanense strains should be classified in the genus Mesorhizobium, but further work is needed to establish the relationship of these organisms with other species in the genus.

The phylogenetic relationships among some generic type strains belonging to the alpha subdivision of the Proteobacteria are shown in Fig. 1. This tree clearly illustrates the unique position of the new genus Mesorhizobium and the phylogenetic distance between the genus Mesorhizobium and the remaining members of the genus Rhizobium.

Description of Mesorhizobium gen. nov. Mesorhizobium (Me. so.rhi.zo'bi.um. Gr. adj. mesos, middle; M. L. neut. n. Rhizobium, bacterial generic name; M. L. neut. n. Mesorhizobium, rhizobia phylogenetically intermediate between the genera Bradyrhizobium and Rhizobium). Cells are gram-negative, aerobic, non-spore-forming rods, motile, usually with one polar or subpolar flagellum. Cells may contain polybetahydroxybutyrate inclusion bodies. Growth on yeast mannitol agar produces colonies that are 2 to $4 \mathrm{~mm}$ in diameter after incubation for 3 to 7 days at $28^{\circ} \mathrm{C}$. All species assimilate glucose, rhamnose, and sucrose with the production of acidic end products. Strains generally form nitrogen-fixing nodules on the roots of a restricted range of leguminous plants, and cross-inoculation between the strains of one species of this genus and the plant hosts associated with another species is not known. The guanine-plus-cytosine contents of the DNAs are 59 to $64 \mathrm{~mol} \%$ (as determined by the thermal denaturation method). The type species is Mesorhizobium loti (Jarvis et al. 1982) comb. nov.

At the molecular level members of this genus can be recognized by their fatty acid profiles (21a) and their 16S rRNA gene sequences.

Description of Mesorhizobium ciceri (Nour et al. 1994) comb. nov. The phenotypic description of Mesorhizobium ciceri is the same as that given by Nour et al. (17). In addition, this species can be differentiated from other Mesorhizobium species by the results of comparative fatty acid analysis, DNA-DNA hybridization, and 16S rRNA gene sequence analysis.

Description of Mesorhizobium huakuii (Chen et al. 1991) comb. nov. The phenotypic description of Mesorhizobium huakuii is the same as that given by Chen et al. (3). In addition, this species can be differentiated from other Mesorhizobium species by the results of comparative fatty acid analysis, DNA-DNA hybridization, and $16 \mathrm{~S}$ rRNA gene sequence analysis.

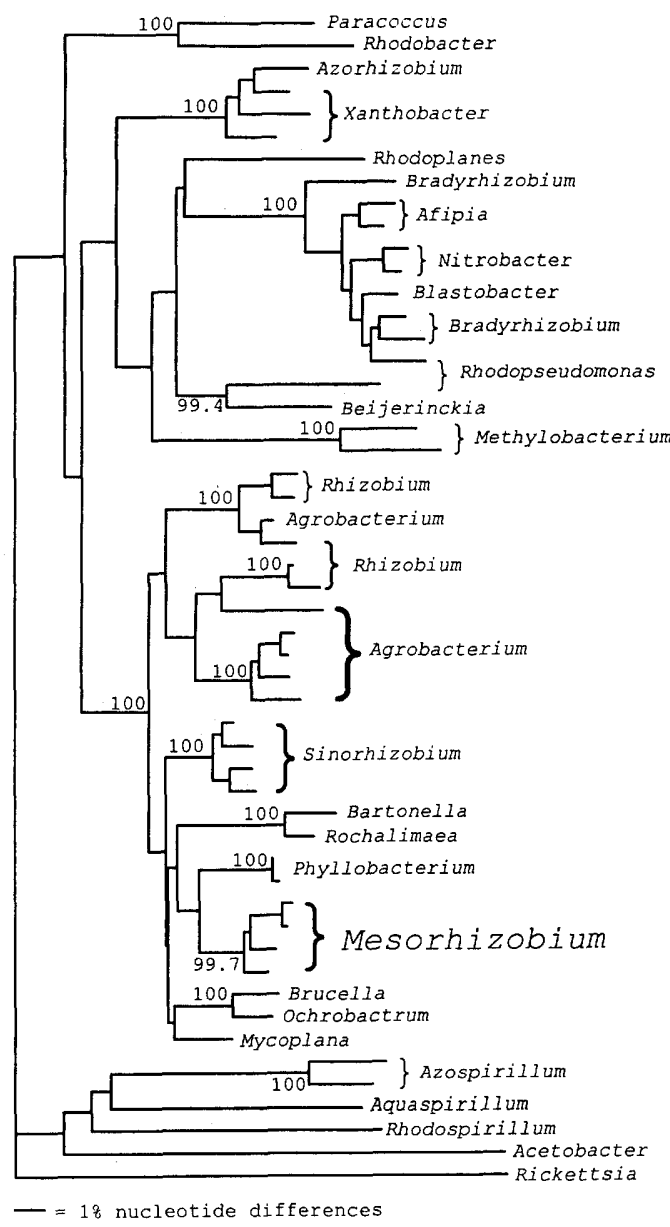

FIG. 1. Phylogenetic relationship of the genus Mesorhizobium within the $\alpha$ subdivision of the class Proteobacteria based on aligned sequences of the smallsubunit rRNA genes. Jukes-Cantor distances were derived from the aligned sequences and used to construct an optimal unrooted tree by the neighborjoining method. A total of 1,000 replicate trees were generated in a bootstrap analysis to derive a majority rule consensus tree. The levels of support that exceeded $99 \%$ are indicated at the nodes on the neighbor-joining tree. The sequences representing the genera indicated on the tree which were used in the phylogenetic analysis were the sequences of Paracoccus denitrificans (accession no. X69159), Rhodobacter sphaeroides (D16425), Azorhizobium caulinodan (X94200), Xanthobacter flavus (X94199), Xanthobacter autotrophicus (X94201) Xanthobacter agilis (X94198), Rhodoplanes roseus (D25313), Bradyrhizobium elkanii (U35000), Bradyrhizobium japonicum (U69638 and Z35330), Afipia clevelandensis (M69186), Afipia felis (M65248), Nitrobacter hamburgensis (L35502) Nitrobacter winogradskyi (L35507), Blastobacter denitrificans (S46917), Rhodopseudomonas palustris (D25312), Rhodopseudomonas acidophyla (M34128), Beijerinckia indica (M59060), Methylobacterium sp. strain BF10 (Z23156), Methyl obacterium extorquens (D32224), Rhizobium leguminosarum bv, viciae (U29386), Rhizobium etli (U28916), Rhizobium tropici (D11344), Rhizobium sp. strain OK 55 (D14510), Rhizobium galegae (X67226), Agrobacterium tumefaciens bv. 2 strain NCPPB2991 (D14501), Agrobacterium vitis (D14502), Agrobacterium rubi (D14503), Agrobacterium tumefaciens NCPPB1650 (D14506), Agrobacterium tumefaciens bv. 1 strain NCPPB2437 (D14500), Agrobacterium sp. strain 3-10 (Z30542), Sinorhizobium fredii (X67231), Sinorhizobium meliloti (X67222), Sinorhizobium saheli (X68390), Sinorhizobium teranga (X68387), Bartonella bacilliformis (M65249), Rochalimaea henselae (M73229), Phyllobacterium myrsinaceanum (D127890), Phyllobacterium rubiacearum (D12790), Mesorhizobium ciceri (U07934), Mesorhizobium loti (X67229), Mesorhizobium mediterraneum (L38825), Mesorhizobium huakuii (D13431), Brucella neotomae (L26167), Ochrobactrum anthropi (D12794), Mycoplana dimorpha (D12786), Azospirillum brasilense (Z29617), Azospirillum lipoferum (Z29619), Aquaspirillum magnetotacticum (M58171), Rhodospirillum rubrum (D30778), Acetobacter diazotrophicus (X75618), and Rickettsia rickettsii (M21293). The sequences were aligned by using the PILEUP program in the Wisconsin package of the Genetics Computer Group (Madison, Wis.). The aligned sequences were analyzed by using the SEQBOOT, DNADIST, NEIGHBOR, and CONSENSE programs of the PHYLIP, version $3.5 \mathrm{c}$ software package $(6)$, and the tree was constructed by using DRAWGRAM. 
Description of Mesorhizobium loti (Jarvis et al. 1982) comb. nov. The phenotypic description of Mesorhizobium loti is the same as that given by Jarvis et al. (9) and supplemented by Nour et al. (16) and De Lajudie et al. (5). In addition, this species can be differentiated from other Mesorhizobium species by the results of comparative fatty acid analysis, DNA-DNA hybridization, and $16 \mathrm{~S}$ rRNA gene sequence analysis.

Description of Mesorhizobium mediterraneum (Nour et al. 1995) comb. nov. The phenotypic description of Mesorhizobium mediterraneum is the same as that given by Nour et al. (16). In addition, this species can be differentiated from other Mesorhizobium species by the results of comparative fatty acid analysis, DNA-DNA hybridization, and 16S rRNA gene sequence analysis.

Description of Mesorhizobium tianshanense (Chen et al. 1995) comb. nov. The phenotypic description of Mesorhizobium tianshanense is the same as that given by Chen et al. (2). In addition, this species can be differentiated from other Mesorhizobium species by the results of $16 \mathrm{~S}$ rRNA gene sequence analysis.

We thank the following persons for helpful discussions: Kristina Lindström, Esperanza Martinez-Romero, Clive Ronson, Scott Tighe, and Peter Young.

\section{REFERENCES}

1. Abdel-Ghaffar, A. S., and H. L. Jenson. 1966. The rhizobia of Lupinus densiflorus Benth., with some remarks on the classification of root nodule bacteria. Arch. Microbiol. 54:393-405.

2. Chen, W., E. Wang, S. Wang, Y. Li, X. Chen, and Y. Li. 1995. Characteristics of Rhizobium tianshanense sp. nov., a moderately and slowly growing root nodule bacterium isolated from an arid saline environment in Xinjiang, People's Republic of China. Int. J. Syst. Bacteriol. 45:153-159.

3. Chen, W. X., G. S. Li, Y. L. Qi, E. T. Wang, H. L. Yuan, and J. L. Li. 1991 Rhizobium huakuii sp. nov. isolated from the root nodules of Astragalus sinicus. Int. J. Syst. Bacteriol. 41:275-280.

4. Crow, V. L., B. D. W. Jarvis, and R. M. Greenwood. 1981. Deoxyribonucleic acid homologies among acid-producing strains of Rhizobium. Int. J. Syst. Bacteriol. 31:152-172.

5. De Lajudie, P., A. Willems, B. Pot, D. Dewettinck, G. Maestrojuan, M. Neyra, M. D. Collins, B. Dreyfus, K. Kersters and M. Gillis. 1994. Polyphasic taxonomy of rhizobia: emendation of the genus Sinorhizobium and descrip tion of Sinorhizobium meliloti comb. nov., Sinorhizobium saheli sp. nov., and Sinorhizobium teranga sp. nov. Int. J. Syst. Bacteriol. 44:715-733.

6. Felsenstein, J. 1993. PHYLIP (phylogenetic inference package), version 3.5c. Department of Genetics, University of Washington, Seattle.

7. Jarvis, B. D. W., M. Gillis, and J. De Ley. 1986. Intra- and intergeneric similarities between the ribosomal ribonucleic acid cistrons of Rhizobium and Bradyrhizobium species and some related bacteria. Int. J. Syst. Bacteriol. 36:129-138.

8. Jarvis, B. D. W., T. S. MacLean, I. G. C. Robinson, and G. R. Fanning. 1977 Phenetic similarity and DNA base sequence homology of root nodule bacteria from New Zealand native legumes and Rhizobium strains from agricultural plants. N. Z. J. Agric. Res. 20:235-248.
9. Jarvis, B. D. W., C. E. Pankhurst, and J. J. Patel. 1982. Rhizobium loti, a new species of legume root nodule bacteria. Int. J. Syst. Bacteriol. 32:378-380.

10. Jarvis, B. D. W., S. Sivakumaran, S. W. Tighe, and M. Gillis. 1996. Identification of Agrobacterium and Rhizobium species based on cellular fatty acid composition. Plant Soil 184:143-158.

11. Jensen, H.-L. 1963. Relations de la plante hote avec les Rhizobium du groupe Lotus-Anthyllis. Ann. Inst. Pasteur (Paris) 105:232-236.

12. Jordan, D. C. 1984. Rhizobiaceae Conn 1938, 321 ${ }^{\mathrm{AL}}$, p. 234-256. In N. R. Krieg and J. G. Holt (ed.), Bergey's manual of systematic bacteriology, vol. 1. The Williams and Wilkins Co., Baltimore, Md.

13. Lindström, K., P. van Berkum, M. Gillis, E. Martinez, N. Novikova, and B. Jarvis. 1995. Report of the round table on Rhizobium taxonomy, p. 807-810. In I. A. Tikhonovich, N. A. Provorov, V. I. Romanov, and W. E. Newton (ed.), Nitrogen fixation: fundamentals and applications. Kluwer Academic Publishers, Dordrecht, The Netherlands.

14. Murphy, P. M., and C. L. Masterson. 1970. Determination of multiple forms of esterases in Rhizobium by paper electrophoresis. J. Gen. Microbiol. 61: 121-129.

15. Nour, S, M., J.-C. Cleyet-Marel, D. Beck, A. Effosse, and M. P. Fernandez. 1994. Genotypic and phenotypic diversity of Rhizobium isolated from chickpea (Cicer arietinum L.). Can. J. Microbiol. 40:345-354.

16. Nour, S. Mo, J-C. Cleyet-Marel, P. Normand, and M. P. Fernandez. 1995. Genomic heterogeneity of strains nodulating chickpeas (Cicer arietinum L.) and description of Rhizobium mediterraneum sp. nov. Int. J. Syst. Bacteriol. 45:640-648.

17. Nour, S. M., M. P. Fernandez, P. Normand, and J.-C. Cleyet-Marel. 1994. Rhizobium ciceri sp. nov. consisting of strains that nodulate chickpeas (Cicer arietinum L.). Int. J. Syst. Bacteriol. 44:511-522.

18. Pankhurst, C. E., and D. R. Biggs. 1980 . Sensitivity of Rhizobium to selected isoflavonoids. Can. J. Microbiol. 26:542-545.

19. Peterson, P. L., R. M. Greenwood, G. B. Belling, and N. O. Bathhurst. 1971 The electrophoretic movement of soluble proteins and the production of unusual amino acids in Rhizobium isolates as taxonomic criteria. Plant Soil 1971(Spec. Vol.):111-114.

20. Roberts, G. P., W. T. Leps, L. E. Silver, and W. J. Brill. 1980. Use of two-dimensional polyacrylamide gel electrophoresis to identify and classify Rhizobium strains. Appl. Environ. Microbiol. 39:414-422.

21. Sawada, H., H. Ieki, H. Oyaizu, and S. Matsumoto. 1993. Proposal for rejection of Agrobacterium tumefaciens and revised descriptions of Agrobacterium radiobacter and Agrobacterium rhizogenes. Int. J. Syst. Bacteriol. 43: 694-702.

21a.Tighe, S. W. Personal communication.

21b.van Berkum, P. Unpublished data.

22. Vincent, J. M. 1974. Root nodule symbioses with Rhizobium, p. 265-341. In A. Quispel (ed.), The biology of nitrogen fixation. Elsevier Publishing Co., New York, N.Y.

23. Vincent, J. M., and B. Humphrey. 1970. Taxonomically significant group antigens in Rhizobium. J. Gen. Microbiol. 63:379-382.

23a.Wang, E. T. Personal communication.

24. Willems, A., and M. D. Collins. 1993. Phylogenetic analysis of rhizobia and agrobacteria based on 16S rRNA gene sequences. Int. J. Syst. Bacteriol. 43:305-313.

25. Yanagi, M., and K. Yamasato. 1993. Phylogenetic analysis of the family Rhizobiaceae and related bacteria by sequencing of 16S rRNA gene using PCR and DNA sequencer. FEMS Microbiol. Lett. 107:115-120.

26. Young, J. P. W. 1996. Phylogeny and taxonomy of rhizobia. Plant Soil 186: $45-52$.

27. Young, J. P. W., and K. E. Haukka. 1996. Diversity and phylogeny of rhizobia. New Phytol. 133:87-94. 